\title{
TECHNICAL EFFICIENCY OF VIETNAMESE MANUFACTURING FIRMS: DO FDI SPILLOVERS MATTER?
}

\author{
Canh NGUYEN ${ }^{1 *}$, Minh $\mathrm{LE}^{2}$, Khoa CAI ${ }^{3}$, Michel SIMIONI ${ }^{4}$ \\ ${ }^{1}$ Center for Economic and Financial Research, University of Economics and \\ Law, Vietnam National University-Ho Chi Minh City, Vietnam \\ ${ }^{2}$ International Economic Faculty, Banking University, Ho Chi Minh City, Vietnam \\ ${ }^{3}$ Finance Faculty, Industrial University, Ho Chi Minh City, Vietnam \\ ${ }^{4}$ Institut National de la Recherche Agronomique, Montpellier, France
}

Received 23 December 2019; accepted 03 December 2020

\begin{abstract}
This paper investigates the spillover effect (backward, forward, and horizontal linkage) of foreign direct investment (FDI) firms on the technical efficiency of local firms. This research extends the literature by employing meta-frontier framework analysis which is superior to single stochastic analysis because each industry has a different combination of inputs (or dissimilar production technology). Using a large data set (178,700 firm-year observations), this paper finds evidence on the negative impact of the horizontal and forward linkages on the meta-technical inefficiency for the data set as a whole as well as in three economic regions, in private owned firms, and capital and labor-intensive sectors in Vietnam.
\end{abstract}

Keywords: meta-frontier framework, meta translog inefficiency, backward, forward, and horizontal linkage, foreign direct investment, Vietnam.

JEL Classification: F61, M21, O30.

\section{Introduction}

Technical efficiency is a fundamental issue in applied economics because it measures how efficient a firm is in comparison with other peers. Foreign direct investment (FDI) is also an important investment channel for developing countries where financial markets are underdeveloped. Hence, there have been many studies on the spillover effects of FDI on local enterprises in developing countries (Ayyagari \& Kosová, 2010; Brown et al., 2006; Iwasaki \& Tokunaga, 2016; Javorcik \& Spatareanu, 2011). However, previous studies employ a single production frontier for different manufacturing sectors (i.e. all sectors use the same technology for their production) to estimate the spillover effect. Our paper extends the literature on the spillover effect of foreign by using meta-frontier framework analysis, which allows firms

*Corresponding author. E-mail: canhnt@uel.edu.vn

Copyright (c) 2021 The Author(s). Published by Vilnius Gediminas Technical University

This is an Open Access article distributed under the terms of the Creative Commons Attribution License (http://creativecommons. org/licenses/by/4.0/), which permits unrestricted use, distribution, and reproduction in any medium, provided the original author and source are credited. 
in different sectors to adopt distinct technologies. The adoption of the meta frontier model is important because firms in different industries have differences in production opportunities, physical assets, human and financial capital.

Technical efficiency is the relative effectiveness among firms in which how a firm produces its output from a set of inputs. A firm is examined to be more efficient if the firm produces more outputs from a certain amount of inputs. Efficiency is important as firms try to use inputs more efficiently and push inefficient ones out of their market under competitive pressures. Moreover, efficiency is a vital issue because the efficient structure hypothesis predicts that efficient firms defeat their inefficient competitors (Demsetz, 1973; Peltzman, 1977).

Spillover effects of FDI may occur via either horizontal or vertical dimensions. Firstly, horizontal spillovers (or intra-industry ones) refer to how FDI firms affect local ones in one industry. On the one hand, domestic firms can benefit from certain positive externalities to increase productivity when FDI firms come with advanced technologies. This positive spillover is called a demonstration effect. On the other hand, FDI firms might come with a crowd out effect in which the market share of local firms is thinner and thinner (Aitken \& Harrison, 1999; Caves, 1996). The net impact of FDI firms on local ones in the same sector depends on the interaction between the demonstration and competition effects. The horizontal spillovers are positive if the demonstration effect outweighs the competition effect (Ni et al., 2017). Secondly, vertical spillovers (inter-industry ones) indicate how FDI firms affect local suppliers in upstream industries (backward linkages) and local customers in downstream industries (forward linkages). Spillovers through backward linkages may exist if the productivity of local firms improves due to the presence of foreign firms in downstream industries. For example, the gain in productivity may come when local firms supply inputs to FDI firms. Spillovers through forward linkages may occur when the productivity of local firms expands when they use either better-quality intermediate inputs or complimentary services from FDI firms.

Vietnam is an interesting case to examine the spillovers of FDI firms in local firms. Implementing the policy of economic innovation, the Law on Foreign Investment in Vietnam, issued in 1987, is one of the starting laws for the renovation period, creating a legal environment to attract foreign investment in Vietnam. In 2005, the National Assembly of Vietnam promulgated the Investment Law to replace the Foreign Investment Law and the Law on Domestic Investment Promotion. The Investment Law was established to improve the investment environment, business environment, create unity in the legal system of investment and create an "equal playing field" without discrimination among investors. By the end of 2017, the number of FDI enterprises has increased to 14,600 enterprises among 477,808 enterprises in Vietnam. The fact also shows that integration, Vietnam has attracted many FDI enterprises and these enterprises play an important role in increasing investment, creating jobs, increasing total export turnover, and increasing Vietnam's economic growth.

Though Vietnam is a country attracting many FDI firms and technical efficiency is important, there are no previous studies that investigate how FDI spillovers affect the technical efficiency of local firms. Previous studies mainly focus on productivity. For example, Le and Pomfret (2011) find a negative horizontal linkage. Anwar and Nguyen (2014) find a strong positive impact of FDI on TFP through backward linkages in some regions but a negative impact in other regions. However, Ramstetter and Ngoc (2013) do not find evidence on 
spillovers of FDI firms to local firms. Ni et al. (2017) used a panel dataset that covers 10 years from 2002 to 2011 and I-O table 2007 to analyze how the origin of FDI firms affects spillovers. Their findings show a positive correlation between Asian firms in downstream industries and the productivity of local firms in supply industries, but no significant evidence for FDI firms from Europe and North America. Though there are several studies on FDI spillover effects, however, the question of whether FDI spillovers contribute to improvement in the technical efficiency of local firms in Vietnam has not been answered. More important is that the previous studies employ a single frontier analysis that assumes firms in different sectors apply the same technology (production method) to produce outputs. This assumption is unreal, creating a research gap for us to fill in by employing meta-frontier analysis.

This study employs translog production functions to capture technical efficiency via a meta-frontier model proposed by Huang et al. (2014). The meta-frontier one is used because firms in different industries may face distinctive production opportunities, originating from differences in available stocks of physical, human and financial capital, resource endowments, etc. Such differences ignite the idea of estimating unique production frontiers for firms in different industries. This paper is a pioneer in employing the meta-frontier approach to estimate the impact of FDI linkages on firm efficiency in the literature.

Research data includes 97,014 unique firms with 178,700 firm-year observations. The source of data is from the Vietnam Annual Enterprise Survey (VAES) and collected from the General Statistic Office (GSO) of Vietnam. Our research provides evidence that the presence of FDI firms in upstream sectors imposes a positive and significant effect on the technical efficiency (TE) of local firms in downstream sectors. Moreover, only local private firms enjoy a positive effect. And firms in the North and Middle economic zones have a lower level of technical efficiency than firms in the Southern one.

This paper includes sections. Section 1 summarizes the previous literature relating to the spillover effects of FDI, showing that FDI firms have different effects on the total productivity of local firms. Section 2 describes the meta-frontier methodology whereby that each industry has its frontier. Relying on these frontiers, this paper constructs the metafrontier to estimate the efficiency of each firm. Section 2 also describes firm-year data in Vietnam. Section 3 presents both baseline and robust research results and last section conveys the conclusions.

\section{Literature}

Firms can improve their performance via innovation activities. The activities can take place in the form of the introduction of new products, better production methods, and novel organization techniques (Schumpeter, 1912). Innovation can change firm performance through two channels. First, innovation increases sales and market shares by different their products from those of rivals (Wang \& Wei, 2005). Second, innovation also changes production technology and thus reduces the cost of producing an additional product (Peters, 2008). By fostering sales, market share and reducing costs, innovation has a positive impact on firm performance in terms of market power and operating profit margin (Dhanora et al., 2018). Technological innovations thus influence the current competition of a firm and in an industry. 
Innovation can come together with foreign direct investment (FDI). Not merely longterm investment that involves the injection of foreign funds into an enterprise, FDI can help local firms to catch up with international technology. The presence of FDI can foster the transfer of both soft technologies such as management skills, information - know-how (Djankov \& Hoekman, 2006) and hard ones (machinery and blueprints). Via the establishing of the new operation, mergers and acquisitions, joint-venture with a local partner, FDI can have a positive impact on externalities or productivity spillovers. The basic premise supporting this positive effect is that foreign-invested firms have superior knowledge and technology which can be transferred through their interactions (backward and forward linkages) with local firms (Markusen \& Venables, 1999).

Spillovers have been investigated in the literature via two mechanisms. First, horizontal (or intra-industry), knowledge and technology transfer can bring in spillovers in FDI firms to compete with their rivals in the same industry. The transfer may arise due to the labour movement with learned knowledge from foreign firms to local firms. Similarly, local firms may copy the technologies by observing how FDI firms operate. The presence of FDI firms is theoretically considered to be the source of positive spillovers to domestic firms because most standard models of FDI assume FDI firms possess some special knowledge such as production technology, managerial skills, and marketing know-how. These assets are believed to be essential for FDI firms in the competition with local firms who also have some special assets such as local market familiarity, their consumers and supply chains. The possible combination of special assets of both FDI and local firms can improve the productivity of the whole sector via knowledge spilling from FDI firms to local ones. However, most scholars agree that intra-industry spillovers are unlikely to happen (Blalock \& Gertler, 2008; Javorcik, 2004). Lu, Tao, and Zhu (2017) are among the few scholars who find evidence of the negative spillover effect of horizontal FDI in China via the agglomeration effect ${ }^{1}$ and the competition effect ${ }^{2}$ (Blomström \& Kokko, 1998).

Second, vertical (or inter-industry), the supply chain from and to between FDI producers and local ones can result in positive spillovers. Most previous studies find evidence of vertical spillovers, which can be either positive or negative, in terms of backward linkages from FDI firms to local suppliers. On the bright side, direct backward linkages occur when local firms experience productivity enhancement due to their supplying inputs to FDI firms. The productivity enhancement can take place as a result of scale economies (from higher outputs) and increased competition from foreign rivals (Javorcik, 2004). On the dark side, negative spillovers are possible for local firms in downstream sectors as FDI firms have more bargaining power on pricing negotiations or require higher standards of inputs. Thus negative spillovers can materialize in the form of lower profits, a loss in productivity in domestic firms (Girma et al., 2008; Rodríguez, 1996). In transition economies, a large number of previous studies have investigated the foreign ownership effect (or direct effect) and the productivity spillover effect (or indirect effect). Regarding the direct effect, a positive effect of foreign ownership on

\footnotetext{
${ }^{1}$ Local firms may enjoy a positive agglomeration effect from FDI firms through input sharing, knowledge spillovers, and labour pooling.

${ }^{2}$ Local firms may have a smaller market share because FDI firms are more productive.
} 
firm performance has been verified using systematic views and meta-analysis (Brown et al., 2006; Iwasaki, 2007; Iwasaki \& Tokunaga, 2016). In contrast, the indirect effect is divergent. Iwasaki and Tokunaga (2016) find a positive effect on the effect size and the statistical significance of the direct effect of FDI are higher than the indirect one via a meta-analysis in Central and Eastern Europe and the former Soviet Union. In Lithuania, Javorcik (2004) finds positive spillovers from FDI joint-venture firms to local ones in different sectors. In China, Lin et al. (2009) show a positive correlation between productivity improvement and FDI firms in upstream and downstream sectors. More recently in China, Huang and Yang (2020) and Huang and Zhang (2020) find that FDI stimulates innovation and productivity of local firms. Similarly, Zhang (2019) provides evidence of larger vertical spillovers through the backward and forward linkages in regions with better intellectual property rights protection in China.

The local firm could improve efficiency for the same reasons when dealing with multinational suppliers. Some articles focus on how the origin of FDI can explain the spillover variation of local firms. Javorcik and Spatareanu (2011) find a positive effect from the presence of American companies in downstream sectors on the productivity of Romanian firms in upstream sectors. Countries of origin of FDI matters in the Czech Republic when horizontal spillovers are driven by FDI from the EU countries (Ayyagari \& Kosová, 2010). In Vietnam, Ni et al. (2017) show a positive relationship between the presence of Asian firms in downstream sectors and the productivity of local firms in upstream industries. Within Asia, FDI firms from China and Taiwan generates positive vertical spillovers to local suppliers. The institutional similarity may be the reason for the positive vertical effects as China and Vietnam share a free market with the communist orientation system. Therefore, Chinese firms better understand local firms. Similarly, Taiwanese firms have invested in mainland China so they also capture the experience from China and then apply in Vietnam.

Previous studies have considered the spillover effects of FDI firms on local firms using a single stochastic frontier analysis. One disadvantage of the approach lies at the assumption that firms in all sectors face the same technology (production method). This assumption is unreal and lay a research gap for us to examine the spillover effects using the meta-frontier production function. Besides, previous studies limit their investigation at an aggregate level (i.e. a whole country or a group of countries). It may be useful to examine the spillover effects by different economic zones within a country, location of firms (inside and outside industrial zones), and ownership (private economy and state economy) can bring in more interesting implications to policy-makers.

\section{Methodology and data}

\subsection{Method}

To examine the impact of FDI spillover on the technical efficiency of firms in Vietnam, this paper initially measures the linkages, productivity, and then finds the correlation between them. 


\subsubsection{Linkages}

This section presents the measurement of forward, backward and horizontal linkages. The horizontal linkage is captured by the following formula:

$$
\text { Horizontal }_{j t}=\sum_{i \text { for all } i \in j} \text { Foreign Share }_{i t} \times Y_{i t} / \sum_{i \text { for all } i \in j} Y_{i t} \text {, }
$$

in which Horizontal $_{j t}$, measuring the level of foreign presence in sector $j$ at time $t$, is defined as foreign equity participation averaged over all firms in the sector, weighted by each firm's

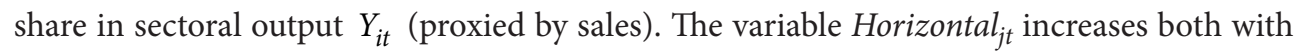
the share of foreign ownership within the sector and with the sales of foreign firms within the same sector.

Relying on the horizontal linkage, this paper measures backward linkage as below:

$$
\text { Backward }_{j t}=\sum_{k i f k \neq j} \alpha_{j k} \text { Horizontal }_{k t}
$$

in which Backward $_{j t}$ captures the extent of the foreign presence in the industries that are being supplied by sector $j$. The value of Backward ${ }_{j t}$ measures the extent of potential contacts between domestic suppliers and foreign-invested firms. Where $\alpha_{j k}$ is the proportion of sector $j$ 's output supplied to sector $k$. The proportion is computed including imports of intermediate products but excluding products supplied for final consumption. The variable Backward $_{j t}$ receives higher value when there is the greater the foreign presence in sectors supplied by industry $j$ and the larger the share of intermediates supplied to industries with the FDI presence.

The forward linkage is measured as:

Forward $_{j t}=\sum_{m i f m \neq j} \delta_{j m}\left[\left[\sum_{i \text { for all } i \in m}\right.\right.$ ForeignShare $\left.\left._{i t} \times\left(Y_{i t}-X_{i t}\right)\right] /\left[\sum_{i \text { for all } i \in m}\left(Y_{i t}-X_{i t}\right)\right]\right]$.

The forward linkage is calculated by the weighted share of output in upstream (or supplying) sectors produced by firms with foreign capital participation. As only intermediates sold in the local market are relevant to this study, goods and services produced by FDI firms for exports $\left(X_{i t}\right)$ are excluded. $\delta_{j m}$ is the share of inputs purchased by industry $j$ from industry $m$ in total inputs sourced by sector $j$. Similarly, inputs purchased within the sector are excluded. The variable Forward $_{j t}$ increases with a greater share of FDI firms in the output of upstream sectors.

\subsubsection{Meta production function}

This paper uses the meta-production function based on a two-stage framework developed by Huang et al. (2014). This paper opts for the meta-production function because each industry has a different production technology, thus it is necessary to decompose the efficiency scores of various groups into technical efficiency and technology gaps. The production stochastic frontier of an industry is as below: 


$$
Y_{j i t}=f_{t}^{j}\left(X_{j i t}\right) e^{V_{j i t}-U_{j i t}}, j=1,2, \ldots, J ; i=1,2, \ldots, N_{j} ; t=1,2, \ldots, T,
$$

where $Y_{j i t}$ and $X_{j i t}$ denote the vectors of outputs and inputs of firm $i$ in year $t$ at industry $j$. $f_{t}^{j}\left(X_{j i t}\right)=e^{X_{j i t} \beta_{t}^{j}}$, where $\beta_{t}^{j}$ stands for the parameters associated with the industry-j frontier. The $V_{j i t}$, which is distributed independently and identically as $N\left(0, \sigma_{v}^{j 2}\right)$, represents statistical noise, and the non-negative random errors $U_{j i t}$, which follows the truncated-normal distribution as $N^{+}\left(\mu^{j}\left(Z_{j i t}\right), \sigma_{u}^{j 2}\left(Z_{j i t}\right)\right)$, represents technical inefficiency. In our paper, there are 10 industries, namely food and foodstuff, garment and textile, wood products, paper, printing products, chemical products, construction materials, metal products, electric and electronic products, and mechanics. A firm technical efficiency (TE) is then defined a

$$
T E_{i t}^{j}=\frac{Y_{j i t}}{f_{t}^{i}\left(X_{j i t}\right) e^{V_{j i t}}}=e^{-U_{j i t}} .
$$

The common underlying meta-frontier production function for all industries is defined as $f_{t}^{M}\left(X_{j i t}\right)$. The meta-frontier envelops all individual industries' frontiers $f_{t}^{j}\left(X_{j i t}\right)$, which is expresses with the following relation.

$$
f_{t}^{j}\left(X_{j i t}\right)=f_{t}^{M}\left(X_{j i t}\right) e^{U_{j i t}^{M}}, \forall j, i, t,
$$

where $U_{j i t}^{M} \geq 0$ and thus $f_{t}^{j}\left(X_{j i t}\right) \leq f_{t}^{M}\left(X_{j i t}\right)$. The technology gap ratio (TGR) is defined as

$$
T G R_{i t}^{j}=\frac{f_{t}^{j}\left(X_{j i t}\right)}{f_{t}^{M}\left(X_{j i t}\right)}=e^{-U_{j i t}^{M}} \leq 1 .
$$

The meta efficiency (MTE) is an efficiency relative to the meta frontier. Therefore, the meta efficiency is a product of group efficiency $T E_{i t}^{j}$ and the gap ratio $\left(T G R_{i t}^{j}\right)$ as below

$$
M T E_{j i t}=\frac{Y_{j i t}}{f_{t}^{M}\left(X_{j i t}\right) e^{V_{j i t}}}=T G R_{i t}^{j} \times T E_{i t}^{j} .
$$

For estimation purpose, this paper employs a meta-framework of the translog production functions (each sector has its production technology so a different production frontier) that can be represented by the following three-input, one output production function:

$$
Y_{i t}=f\left(K_{i t}, L_{i t}, M_{i t}, t\right)
$$

where $Y_{i t}$ denotes a firm's output, $K_{i t}, L_{i t}$ and $M_{i t}$ are production inputs: capital, labor, and materials. Subscripts i and t refer to firm and year, respectively. A firm's output is defined as total revenues, labor as the number of employees and materials as the value of intermediate input. The production function itself is allowed to shift over time to account for technological change. 
This paper specifies production function into the trans-log production function, which allows greater flexibility and produces more realistic efficiency scores to the Cobb-Douglas form. This research, therefore, follows Lin and Atsagli (2017) and Bölük and Koç (2010) in employing the three-input trans-log production function and expressing the variables in logarithms as shown in Eq. (10), with accounting for technological change (Feng \& Serletis, 2008; Biørn \& Skjerpen, 2004). The equation is run for each industry to capture (in)efficiency level for year $\mathrm{t}$ and firm $\mathrm{i}$ in the same sector. Therefore, each sector has a frontier which is estimated by Eq. (10):

$$
\begin{gathered}
\log \left(Y_{i t}\right)=\alpha+a_{0} \times \log \left(K_{i t}\right)+a_{1} \times \log \left(L_{i t}\right)+a_{2} \times \log \left(M_{i t}\right)+ \\
b_{0} \times \frac{1}{2} \times\left(\log \left(K_{, i t}\right)\right)^{2}+b_{1} \times \frac{1}{2} \times\left(\log \left(L_{, i t}\right)\right)^{2}+b_{2} \times \frac{1}{2} \times\left(\log \left(M_{, i t}\right)\right)^{2}+ \\
c_{0} \times \log \left(K_{, i t}\right) \times \log \left(L_{, i t}\right)+c_{1} \times \log \left(K_{, i t}\right) \times \log \left(M_{, i t}\right)+c_{2} \times \log \left(M_{, i t}\right) \times \log \left(L_{, i t}\right)+ \\
d_{0} \times \text { Trend }+d_{1} \times \text { Trend }^{2}+d_{2} \times \operatorname{Trend} \times \log \left(K_{i t}\right)+d_{3} \times \text { Trend } \times \log \left(L_{i t}\right)+d_{4} \times \\
\text { Trend } \times \log \left(M_{i t}\right)+\left(v_{i, t}-u_{i, t}\right) .
\end{gathered}
$$

$v_{i, t}$ is a random variable, which is assumed to be i.i.d. distributed as a $N\left(0, \sigma_{v}^{2}\right) . u_{i, t}$ is a non-negative random variable, which is assumed to account for the individual inefficiency in production. $u_{i, t}$ is estimated by truncation at zero of the $N\left(m_{i, t}, \sigma_{u}^{2}\right)$ distribution.

Meta technical inefficiency (MTI) is defined as 1 minus MTE. Eq. (8) tells us MTE can be captured either as a ratio of actual revenue of firm $i$ at industry $j$ in year $t\left(Y_{j i t}\right)$ to its potential revenue $\left(f_{t}^{M}\left(X_{j i t}\right) e^{V_{j i t}}\right)$ or a product of group efficiency $T E_{i t}^{j}$ and the gap ratio $\left(T G R_{i t}^{j}\right)$. Then, MTI is designed to be a function of backward, forward and horizontal linkages as:

$$
M T I_{i, t+1}=f\left(B L K_{i, t}, F L K_{i, t}, H_{i, t}\right) .
$$

This paper follows Battese and Coelli (1995) in estimating a vector for coefficients in Eq. (10) and the coefficients of the explanatory variables $\left(B L K_{i, t}, F L K_{i, t}, H_{i, t}\right)$ in Eq. (11) in one step using maximum likelihood.

Table 1 describes the dependent and independent variables in this paper. Meta technical inefficiency (MTI) is the dependent variable. Key explanatory variables include backward, forward and horizontal linkages (captured in Eq. (1), (2), and (3) respectively). Firm control variables are size (proxied by the logarithm of total assets), EQUITY is equity ratio (the ratio of total equity to total assets), DEXP is a dummy variable takes value one if the firm exports its products, DIMP is a dummy variable that takes the value of one if the firm has import activities, and DINDPARK is a dummy variable that indicates whether the firm is situated inside an industrial park.

This study adds these above control variables for several reasons. First, size can have a positive impact on technical efficiency due to scale economies that help firms to produce products at a lower cost, gain higher profitability and a greater chance of survival. Previous 
Table 1. Definition of variables

\begin{tabular}{|c|c|c|}
\hline Variable & Description & Type \\
\hline \multicolumn{3}{|c|}{ Dependent variables } \\
\hline MTI & Meta technical inefficiency (MTI), computed as $1-$ MTE & Inefficiency \\
\hline \multicolumn{3}{|c|}{ Independent variables } \\
\hline$B L K$ & Backward linkage & Linkage \\
\hline$F L K$ & Forward linkage & Linkage \\
\hline$H$ & Horizontal linkage & Linkage \\
\hline SIZE & The logarithm of total assets & Firm characteristics \\
\hline EQUITY & The ratio of total equity to total assets & Firm characteristics \\
\hline DEXP & $\begin{array}{l}\text { A dummy variable takes value one if the firm exports its } \\
\text { products }\end{array}$ & Firm characteristics \\
\hline DIMP & $\begin{array}{l}\text { A dummy variable that takes the value of one if the firm has } \\
\text { import activities }\end{array}$ & Firm characteristics \\
\hline DINDPARK & $\begin{array}{l}\text { A dummy variable that indicates whether the firm is } \\
\text { situated inside an industrial park }\end{array}$ & Firm characteristics \\
\hline
\end{tabular}

Note: This table shows the definition of variables.

studies (Cai et al., 2019; Le et al., 2018, 2020) have shown that size influenced firm efficiency. second, equity ratio can have a certain impact on efficiency because a higher equity ratio can have a lower cost of capital, lower credit risk (Cai et al., 2019). Third, export and import activities can help firms either increase the quality of their products or reduce the production cost, enhancing competition and efficiency. This argument follows previous studies of (Ba Trung \& Kaizoji, 2017; Liang, 2017). And finally, firms locate inside an industrial park in Vietnam are eligible to have tax incentives. Location choice is a factor to explain differences in sales (Alcacer \& Delgado, 2016).

\subsection{Data}

The data source for production function estimation is the Vietnam Annual Enterprise Survey (VAES) which is conducted by the General Statistics Office (GSO) of Vietnam. Questionnaires are designed for enterprises to provide data to record business activities by December 31 every year. The data include a collection of general information about enterprises, information on inputs for production such as capital, assets, financial situation, investment, human resources, types of input costs ... as well as the results of activities such as revenue, export, profit ... of economic industries in general, including processing manufacturing industry enterprises in all provinces/regions of Vietnam. The survey is designed to measure production inputs and business performance, so data is most suitable for use in estimating production functions, operational efficiency, and impact factors.

Each enterprise code is assigned to a unique industry, based on the industry of the enterprise that accounts for the greatest share of revenues. The sector classification system used here is based on VSIC 2007, which corresponds closely to ISIC Revision 4. Each enterprise is 
also classified by area code as the province code; code of industrial and non-industrial zones, code according to the type of businesses owned by state-owned enterprises, domestic private enterprises, and foreign-invested enterprises.

Table 2. Data processing for the sample of manufacturing firms over the period 2010-2016 (source: authors' calculation from VAES 2010-16)

\begin{tabular}{|c|l|l|c|c|}
\hline Step & \multicolumn{1}{|c|}{ Description } & Result & $\begin{array}{c}\text { No. of } \\
\text { unique } \\
\text { firms }\end{array}$ & $\begin{array}{l}\text { No. of firm- } \\
\text { year obser- } \\
\text { vations }\end{array}$ \\
\hline 1 & $\begin{array}{l}\text { Original datasets obtained from GSO } \\
\text { are merged using firms' geographical } \\
\text { information including province, district, and } \\
\text { commune, and identification }\end{array}$ & $\begin{array}{l}\text { Unbalanced panel } \\
\text { data }\end{array}$ & 136,494 & 426,941 \\
\hline 2 & $\begin{array}{l}\text { Exclude observations with missing and } \\
\text { inconsistent values of total revenues, fixed } \\
\text { assets, number of employees, and material, } \\
\text { i.e. negative or zero values }\end{array}$ & $\begin{array}{l}\text { Unbalanced panel } \\
\text { data }\end{array}$ & 97,458 & 296,377 \\
\hline 3 & $\begin{array}{l}\text { Exclude observations with missing values of } \\
\text { backward, forward, and horizontal linkages }\end{array}$ & $\begin{array}{l}\text { Unbalanced panel } \\
\text { data }\end{array}$ & 97,090 & 294,837 \\
\hline 4 & $\begin{array}{l}\text { Narrow the sample by including only firms } \\
\text { which have consistent annual values of at } \\
\text { least 5 years of consecutively operating }\end{array}$ & $\begin{array}{l}\text { The final unbalanced } \\
\text { panel data as des- } \\
\text { cribed in detail in } \\
\text { Table 3 }\end{array}$ & 97,014 & 178,700 \\
\hline
\end{tabular}

The data sample of manufacturing firms between 2010 and 2016 is taken from the VAES. Several steps of data processing shown in Table 2 are then employed to obtain the final dataset for the analysis. First, the initial data includes 426,941 firm-year observations of manufacturing firms in Vietnam for the period 2010-2016. This paper excludes observations with missing and inconsistent values, i.e. negative or zero values, resulting in 296,377 observations. Then this paper drops observations with missing data needed to investigate the impact of forward, backward, and horizontal linkages on meta technical inefficiency, so this paper achieves an unbalanced panel data sample of 178,700 observations.

Table 3 shows statistical descriptions of our variables. On average, a firm has the BLK of 0.3860 , the FLK of 0.4530 , and the $\mathrm{H}$ of 0.3680 . The mean values of BLK, FLK, and H provide interesting implications from how FDI firms interact with local firms. For example, the mean of $\mathrm{H}$ is 0.3680 , implying that FDI firms on average contribute 36.8 percentage of the total sale in an industry. The mean of BLK is 0.3860 , implying that on average 38.6 percentage of inputs for FDI firms in a sector supplied by local firms in the previous downstream sector. The mean of FLK is 0.4530 , implying that on average 45.3 percentage of inputs for local firms in a sector supplied by FDI firms in the previous downstream sector. Focusing on firm characteristics, a firm has an equity ratio of 41.26 percent, and a log asset value of 9.2821. 31.31 percent of our firm sample relates to export activities and 23.33 percent of the sample does import activities. More than half of the firm sample locates in an industrial park. Regarding meta technical inefficiency (MTI), a firm has an industry technical inefficiency level of 0.1734 , implying that on average a firm can increase its total revenue by 17.34 percent. This 
paper focuses on the meta inefficiency score (MTI) rather than TE, TGR, and MTE because the dependent variable in our analysis is MTI (see Eq. (11)).

Table 3. Summary statistics for the final sample (source: Vietnam's GSO and authors' calculation)

\begin{tabular}{|l|c|c|c|c|c|c|c|c|}
\hline \multicolumn{1}{|c|}{ Variable } & $\mathrm{N}$ & Mean & Min & P25 & Median & P75 & Max & STD \\
\hline MTI & 178,700 & 0.1734 & 0.0224 & 0.1290 & 0.1512 & 0.1869 & 0.9999 & 0.0857 \\
\hline BLK & 178,700 & 0.3860 & 0.0000 & 0.1734 & 0.3793 & 0.5652 & 1.2140 & 0.2553 \\
\hline FLK & 178,700 & 0.4530 & -2.5933 & 0.2125 & 0.3744 & 0.6093 & 2.0256 & 0.4046 \\
\hline$H$ & 178,700 & 0.3680 & 0.0066 & 0.1598 & 0.3896 & 0.5675 & 0.9818 & 0.2294 \\
\hline SIZE & 178,700 & 9.2821 & 2.0044 & 8.0733 & 9.1033 & 10.3863 & 13.3921 & 1.6665 \\
\hline EQUITY & 178,700 & 0.4126 & -0.5166 & 0.2505 & 0.4167 & 0.6279 & 1 & 0.4770 \\
\hline DEXP & 178,700 & 0.3132 & 0 & 0 & 0 & 1 & 1 & 0.4638 \\
\hline DIMP & 178,700 & 0.2333 & 0 & 0 & 0 & 0 & 1 & 0.4229 \\
\hline DINDPARK & 178,700 & 0.5624 & 0 & 0 & 1 & 1 & 1 & 0.4961 \\
\hline
\end{tabular}

Notes: This table describes the summary statistics of the variables in Table 1.

When calculating the impact of FDI spillovers, this paper relies on the two I-O tables of Vietnam implemented by the General Statistics Office (with the support of United Nations experts), including the I-O table of 2007 which calculates the linkage coefficients for the period of 2010-2011; and the I-O table of 2012 using the linkage coefficient for the period 2012-2016. Vietnam's I-O table of 2007 and 2012 has 164 product industries or a group of industry products. The selection of 164 product industries is based on the importance of these industries in the economy and for economic analysis and statistical purposes. Thanks to the support of experts from the General Statistics Office of Vietnam, the product industries in the I-O Table are rearranged according to the industry code of the category used in the annual enterprise survey questionnaire based on the 2007 VSIC.

\section{Research results}

\subsection{Baseline analysis}

The overall goal of this paper is to determine how technical inefficiency relates to FDI presence. This section shows our baseline analysis which shows the impact of lagged explanatory variables (backward, forward, and horizontal linkages) on the meta-technical inefficiency for the whole sample. The impact is captured by the Battese and Coelli (1995) conditional mean model as shown in Eq. (11). Table 4 represents the overall result suggesting that lagged forward and horizontal linkages have a consistent and significant influence on the inefficiency, but backward linkage does not.

The coefficients of backward linkage (BLK) are negative and significant at the 1 percent level in Column 1. This result suggests a negative backward spillover on technical inefficiency from upstream sectors with the presence of foreign firms using inputs from firms in downstream sectors. However, the impact is not consistent since the coefficient of BLK turns 
positive when two other linkages (in Column 4) and firm characteristics (in Column 5) are added.

Table 4. Baseline regression results

\begin{tabular}{|c|c|c|c|c|c|}
\hline & (1) & (2) & (3) & (4) & (5) \\
\hline & \multicolumn{5}{|c|}{ META TRANSLOG INEFFICIENCY $\mathrm{t}_{+1}$} \\
\hline \multirow{2}{*}{$\mathrm{BLK}_{\mathrm{t}}$} & $-670.63^{\star * *}$ & & & $364.05^{\star * *}$ & $567.17^{\star * *}$ \\
\hline & $(24.39)$ & & & $(23.29)$ & $(48.50)$ \\
\hline \multirow{2}{*}{ FLK $_{t}$} & & $-308.65^{\star * *}$ & & $-30.29^{\star * *}$ & $-53.79^{* * *}$ \\
\hline & & $(9.69)$ & & (3.55) & (7.99) \\
\hline \multirow{2}{*}{$\mathbf{H}_{\mathrm{t}}$} & & & $-378.45^{\star \star \star}$ & $-558.11^{\star \star \star}$ & $-826.09^{\star \star *}$ \\
\hline & & & $(13.76)$ & $(7.86)$ & $(69.32)$ \\
\hline \multirow{2}{*}{$\operatorname{SIZE}_{\mathrm{t}}$} & & & & & $-42.85^{\star * *}$ \\
\hline & & & & & $(3.02)$ \\
\hline \multirow{2}{*}{ EQUITY $_{\mathrm{t}}$} & & & & & $89.85^{\star * *}$ \\
\hline & & & & & $(10.40)$ \\
\hline \multirow{2}{*}{$\operatorname{DEXP}_{t}$} & & & & & $19.84^{* \star}$ \\
\hline & & & & & $(8.26)$ \\
\hline \multirow{2}{*}{$\operatorname{DIXP}_{t}$} & & & & & $-102.05^{\star * *}$ \\
\hline & & & & & $(13.80)$ \\
\hline \multirow{2}{*}{ DINDPARK $_{\mathrm{t}}$} & & & & & $69.88^{\star * *}$ \\
\hline & & & & & $(6.50)$ \\
\hline \multirow{2}{*}{ Constant } & $-540.13^{* * *}$ & $-479.03^{* * *}$ & $-211.07^{\star \star *}$ & $-113.53^{\star * *}$ & -11.57 \\
\hline & (13.11) & $(15.90)$ & $(7.09)$ & $(7.86)$ & $(16.45)$ \\
\hline $\mathrm{N}$ & 118,506 & 118,506 & 118,506 & 118,506 & 118,506 \\
\hline
\end{tabular}

Note: This table reports the impacts of backward linkage (BLK), forward linkage (FLK), and horizontal linkage (HLK) on the meta technical inefficiency index obtained through a meta-frontier framework of the translog production function. Control variables include the firm's size (SIZE), the ratio of total equity to total assets (EQUITY), export and import dummies (DEXP and DIMP), a dummy for whether the firm is situated inside of an industrial park (DINDPARK). Standard errors are in brackets. For brevity, the year dummies and coefficients of the translog production function are suppressed. The definition of variables is shown in Table 1 . The period covers the years $2010-2016$. ${ }^{* * *}$ Significant at the $1 \%$ level, ${ }^{*}$ Significant at the $5 \%$ level, ${ }^{*}$ Significant at the $10 \%$ level.

The coefficients of forward linkage (FLK) are negative and significant at the 1 percent level in Columns 2, 4, and 5. The results suggest that foreign presence in downstream sectors has a negative and significant impact on the inefficiency. In other words, FLK has a positive effect on meta efficiency. Our finding on the positive and significant effect of FLK on efficiency is in line with some empirical analyses (Javorcik, 2004; Liang, 2017). This paper assumes that foreign presence in downstream sectors can reduce the meta technical inefficiency (MTI) or increase technical efficiency of upstream firms when they use inputs from foreign firms because of the higher input quality as well as improvement 
of local firms' management in terms of time, quality control, inventory. Better management can lead to a higher level of TE. This finding is opposite to Newman et al. (2015) who find evidence for a negative forward spillover from FDI firms in upstream sectors on the productivity of local firms. This research argues that a forward linkage may take place in Vietnam due to unintended leakage of knowledge from FDI firms to upstream firms. By using inputs provided by FDI firms, the quality of products of upstream firms could become better and selling at a higher price. Domestic firms can ask FDI firms to provide training courses as a requirement attached to the sale contract. The training, product quality and the higher price are channels for spillovers (Halpern et al., 2015).

This paper also finds the foreign presence in the same sector has a negative and significant impact on the inefficiency. The coefficients of horizontal linkage are negative and significant at the 1 percent level in Columns 3, 4, and 5. The results provide strong evidence for negative horizontal spillovers on inefficiency in sectors with the presence of foreign-owned firms. This research assumes that local firms can increase their efficiency by learning superior technologies and management from FDI firms. This process relates to the so-called "demonstration effect" (Ni et al., 2017) via recruiting employees who had been trained and previously employed by the FDI. The existence of horizontal spillovers implies that local firms are possible to have the absorptive capacity necessary to assimilate foreign knowledge. Moreover, the presence of FDI firms may intensify competition in the same industry and raise a fatal need for local firms either to improve efficiency or seek new technologies (Blomström \& Kokko, 1998). And local firms have succeeded in improving their efficiency. As there exists a positive effect of horizontal linkage on efficiency in Vietnam, this paper can conclude that foreign-owned firms do not crowd out local firms in the same industry. This finding is interesting for local firms in Vietnam because the entry of FDI firms leads to an increase in the technical efficiency of local firms.

Among control variables, firm size and the dummy for imports have negative and significant impacts on technical inefficiency. These findings imply to improve performance, firms should become larger and use imported inputs. Size can have a positive impact on technical efficiency due to scale economies that help firms to produce products at a lower cost, gain higher profitability and a greater chance of survival. The positive impact of firm size on efficiency is supported by the research of Le, Vu, and Nghiem (2018). Regarding the dummy for import activity, our result shows that importing plays like a new technology that adds to the technical efficiency of firms. Using imported inputs can increase the quality of products and services and generate a higher selling price. However, equity and the dummy for export activity seem to have negative impacts on technical efficiency. Firms with a higher level of equity may lead to a lower level of technical efficiency because they do not benefit from a leverage effect. The effect implies that firms may generate more revenue and profit from the same level of equity if they use more debts. Firms with exported products may lead to a lower level of efficiency if their exported products are low value-added. To have the same revenue, thus, they have to spend more on better materials, fixed assets and administration cost to ensure the quality of exported products. 


\subsection{Robustness checks}

In the previous section, this research has investigated the impact of the three linkages on technical inefficiency for the whole sample. The baseline results indicate there exists a negative impact of a backward linkage (BLK) and a horizontal one on inefficiency. In this section, three robust checks are done for different firm groups following their location and ownership. Initially, the initial sample is categorized into three economic regions (e.g. northern, central, and southern ones). Then this analysis splits the sample into three firm groups by their ownership: private, state, and FDI firms. Finally, this paper divides the data sample into two groups by firms' capital intensity median. This study shows a statistical table of MTI over different regions, ownership, and the intensity in the Appendix. As the impact of the backward linkage is not consistent in the baseline analysis, this analysis focuses on examining the robustness of the forward and horizontal spillovers in this section.

First, Panel A of Table 5 shows the influence of three spillovers on technical efficiency over three economic regions, namely Northern, Central, and Southern. Across the three regions, the impact of the forward and horizontal spillovers is negative and significant at the 1 percent level. The negative sign of the impact suggests that a higher level of forward and horizontal spillovers is associated with a lower level of inefficiency.

Second, this analysis resamples the data by three ownership types, namely (local) private, state, and foreign. The local private ownership includes cooperatives, private enterprises, partnerships, limited companies, limited companies with less than 50 percent of the stateownership, and joint-stock companies with less than 50 percent of the state-ownership. The state-ownership includes single-member state-owned limited liability companies, limited and joint-stock companies with more than 50 percent of state ownership. And foreign ownership includes foreign direct investment and joint venture firms. Panel B of Table 5 presents the influence of the linkages on firm technical efficiency over the three types of ownership. Coefficients of the forward and horizontal spillovers for private-owned firms are significant whereas those of state-owned and foreign ones are not. These results imply that only privately owned firms enjoy the forward and horizontal spillovers from FDI firms. This finding is important as private-owned firms are drivers of the Vietnamese economy.

Finally, this analysis splits the data sample into two groups by capital intensity. This paper computes the ratio of fixed assets to total assets and resamples by the median of the ratio each year. Firms with a ratio higher than or equal to the median are capital intensive and laborintensive otherwise. Panel C of Table 5 presents the impact of the spillovers on technical efficiency. Coefficients of the forward and horizontal spillovers for both capital-intensive firms and labor-intensive ones are negative and significant. These results show that the impact of FLK and $\mathrm{H}$ are consistent and robust for both capital and labour intensity firms.

In the baseline analysis, this paper finds a negative impact of the forward and horizontal linkages on firm technical inefficiency. In this robustness section, the paper continues to find evidence on a robust influence of the forward and horizontal linkages on firm technical inefficiency over three economic regions, capital- and labor-intensive firms, and over private-owned firms. 


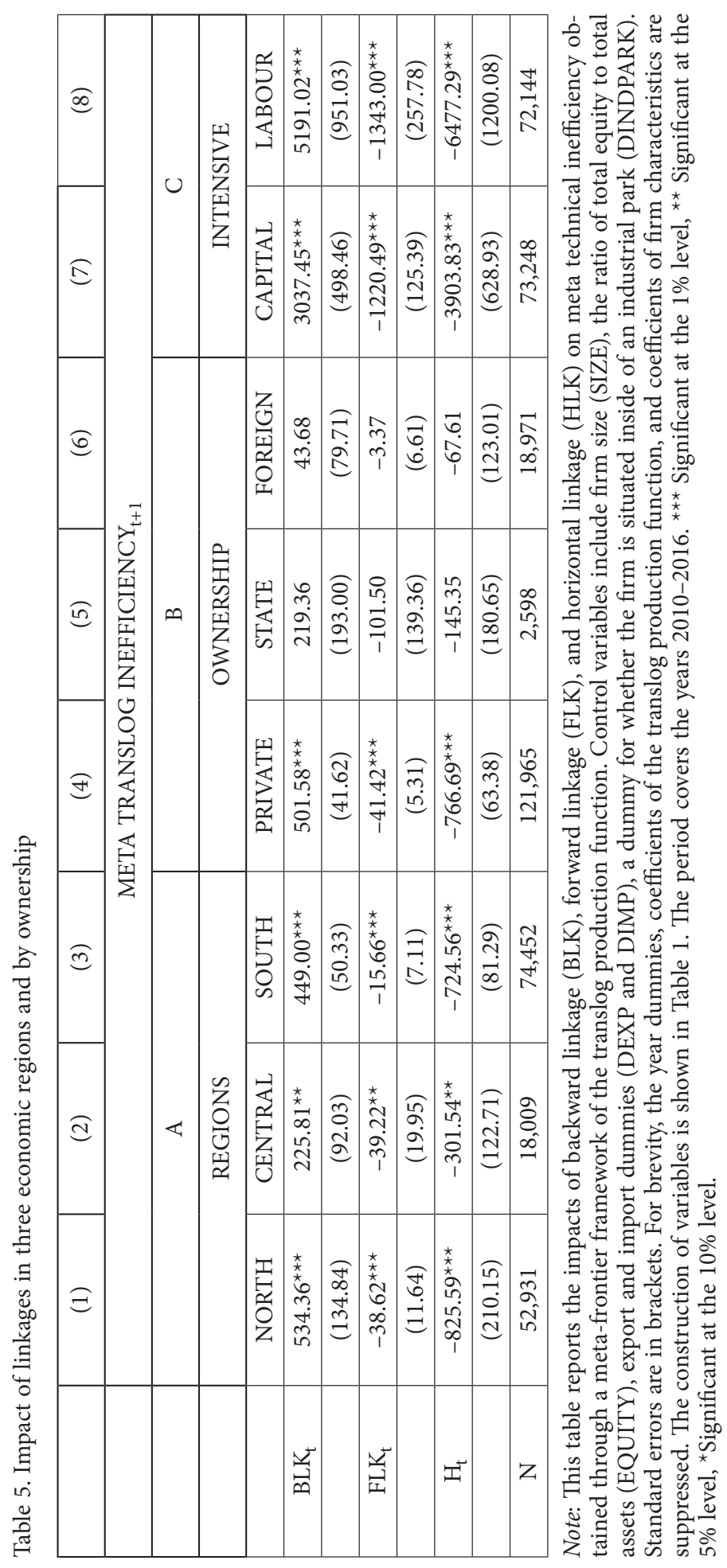




\section{Conclusions}

This study examines the technical spillover taking place between foreign firms and domestic firms in Vietnam. it is expected that the presence of FDI firms may have positive backward, forward, and horizontal spillovers on the technical efficiency of all firms in the country. However, the paper only finds evidence of a negative impact of forward and horizontal linkages of FDI firms on the meta technical inefficiency of private-owned firms in the country. This study differs from previous ones when it extends the literature on the spillover effect of foreign in the sense that this paper employs a meta-frontier framework analysis. This methodology is important because the different sectors have their own production technology. Moreover, previous studies on the spillover effect from FDI firms on local firms use a small observation sample in Vietnam. This study employs a larger sample with 97,014 unique firms and 178,700 firm-year observations.

This research results indicate that the vertical spillover (inter-industry, in downstream sectors-spillovers through forward linkages) and horizontal spillover effects (intra-industry) of the FDI sector to the domestic private sector are recorded. That means domestic private companies of the Vietnamese manufacturing industry benefit from foreign-invested enterprises, supporting the theory of advantages of FDI attraction. However, state-owned enterprises in Vietnam have no linkage effect from the FDI sector.

This study does not find spillovers through backward linkages. This shows that domestic enterprises do not supply inputs for the FDI sector. Domestic enterprises have not yet taken advantage of the local resources "internalizing" the input for the FDI sector to reduce import costs and improve operational efficiency. The implication here is that domestic enterprises should be encouraged to produce supporting industries for themselves and for the FDI sector to reduce import costs. This paper has examined the backward linkage, forward linkage, and horizontal linkage on meta technical inefficiency in Vietnam. Future research can extend this paper by examining the interaction between firm characteristics with these linkages to see how their impact on meta technical inefficiency varies with firm characteristics.

\section{Funding}

This work was funded by Vietnam National University- Ho Chi Minh City (VNU-HCM) under Grant number NCM2019-34-01.

\section{Author contributions}

Canh Nguyen suggests the research ideas and participates in building a research framework, designing a questionnaire to collect data, measuring variables, writing the introduction, describing data, explaining research results and giving policy implications. Canh Nguyen is the corresponding author. Minh Le is responsible for building a research framework, writing a theoretical overview, designing methodology, running models, and interpreting model results. Minh Le also participates in reading and editing manuscripts. Khoa Cai participates in processing data and running models. Michel Simioni proposes the Meta-Frontier approach and guides how to run the model. 


\section{Disclosure statement}

Authors declare that they do not have any competing financial, professional, or personal interests from other parties.

\section{References}

Aitken, B. J., \& Harrison, A. E. (1999). Do domestic firms benefit from direct foreign investment? Evidence from Venezuela. American Economic Review, 89(3), 605-618. https://doi.org/10.1257/aer.89.3.605

Alcacer, J., \& Delgado, M. (2016). Spatial organization of firms and location choices through the value chain. Management Science, 62(11), 3213-3234. https://doi.org/10.1287/mnsc.2015.2308

Anwar, S., \& Nguyen, L. P. (2014). Is foreign direct investment productive? A case study of the regions of Vietnam. Journal of Business Research, 67(7), 1376-1387. https://doi.org/10.1016/j.jbusres.2013.08.015

Ayyagari, M., \& Kosová, R. (2010). Does FDI facilitate domestic entry? Evidence from the Czech Republic. Review of International Economics, 18(1), 14-29. https://doi.org/10.1111/j.1467-9396.2009.00854.x

Ba Trung, N., \& Kaizoji, T. (2017). Investment climate and firm productivity: An application to Vietnamese manufacturing firms. Applied Economics, 49(44), 4394-4409. https://doi.org/10.1080/00036846.2017.1282148

Battese, G. E., \& Coelli, T. J. (1995). A model for technical inefficiency effects in a stochastic frontier production function for panel data. Empirical Economics, 20(2), 325-332. https://doi.org/10.1007/BF01205442

Biørn, E., \& Skjerpen, T. (2004). Aggregation biases in production functions: a panel data analysis of Translog models. Research in Economics, 58(1), 31-57. https://doi.org/10.1016/j.rie.2003.09.004

Blalock, G., \& Gertler, P. J. (2008). Welfare gains from Foreign Direct Investment through technology transfer to local suppliers. Journal of International Economics, 74(2), 402-421. https://doi.org/10.1016/j.jinteco.2007.05.011

Blomström, M., \& Kokko, A. (1998). Multinational corporations and spillovers. Journal of Economic Surveys, 12(3), 1-31. https://doi.org/10.1111/1467-6419.00056

Bölük, G., \& Koç, A. A. (2010). Electricity demand of manufacturing sector in Turkey: A translog cost approach. Energy Economics, 32(3), 609-615. https://doi.org/10.1016/j.eneco.2010.01.007

Brown, J. D., Earle, J. S., \& Telegdy, Á. (2006). The productivity effects of privatization: Longitudinal estimates from Hungary, Romania, Russia, and Ukraine. Journal of Political Economy, 114(1), 61-99. https://doi.org/10.1086/499547

Cai, K., Le, M., \& Vo, H. (2019). The cost of being safer in banking: Market power loss. Economic Analysis and Policy, 62, 116-130. https://doi.org/10.1016/j.eap.2019.01.006

Caves, R. E. (1996). Multinational enterprise and economic analysis. Cambridge University Press.

Demsetz, H. (1973). Structure, market rivalry, and public policy. Journal of Law \& Economics, 16(1), 1-9. https://doi.org/10.1086/466752

Dhanora, M., Sharma, R., \& Khachoo, Q. (2018). Non-linear impact of product and process innovations on market power: A theoretical and empirical investigation. Economic Modelling, 70, 67-77. https://doi.org/10.1016/j.econmod.2017.10.010

Djankov, S., \& Hoekman, B. (2006). Foreign investment and productivity growth in Czech enterprises. Integration \& Technology, 161. 
Feng, G., \& Serletis, A. (2008). Productivity trends in US manufacturing: Evidence from the NQ and AIM cost functions. Journal of Econometrics, 142(1), 281-311.

https://doi.org/10.1016/j.jeconom.2007.06.002

Girma, S., Görg, H., \& Pisu, M. (2008). Exporting, linkages and productivity spillovers from foreign direct investment. Canadian Journal of Economics, 41(1), 320-340.

https://doi.org/10.1111/j.1365-2966.2008.00465.x

Halpern, L., Koren, M., \& Szeidl, A. (2015). Imported inputs and productivity. American Economic Review, 105(12), 3660-3703. https://doi.org/10.1257/aer.20150443

Huang, C. J., Huang, T.-H., \& Liu, N.-H. (2014). A new approach to estimating the metafrontier production function based on a stochastic frontier framework. Journal of Productivity Analysis, 42(3), 241-254. https://doi.org/10.1007/s11123-014-0402-2

Huang, Y., \& Yang, H. (2020). Identifying IFDI and OFDI productivity spatial spillovers: Evidence from China. Emerging Markets Finance and Trade, 56(5), 1124-1145.

https://doi.org/10.1080/1540496X.2018.1553161

Huang, Y., \& Zhang, Y. (2020). The innovation spillovers from outward and inward foreign direct investment: A firm-level spatial analysis. Spatial Economic Analysis, 15(1), 43-59. https://doi.org/10.1080/17421772.2019.1618484

Iwasaki, I. (2007). Enterprise reform and corporate governance in Russia: A quantitative survey. Journal of Economic Surveys, 21(5), 849-902. https://doi.org/10.1111/j.1467-6419.2007.00520.x

Iwasaki, I., \& Tokunaga, M. (2016). Technology transfer and spillovers from FDI in transition economies: A meta-analysis. Journal of Comparative Economics, 44(4), 1086-1114. https://doi.org/10.1016/j.jce.2016.10.005

Javorcik, S. B., \& Spatareanu, M. (2011). Does it matter where you come from? Vertical spillovers from foreign direct investment and the origin of investors. Journal of Development Economics, 96(1), 126-138. https://doi.org/10.1016/j.jdeveco.2010.05.008

Javorcik, S. B. (2004). Does foreign direct investment increase the productivity of domestic firms? In search of spillovers through backward linkages. American Economic Review, 94(3), 605-627. https://doi.org/10.1257/0002828041464605

Le, H. Q., \& Pomfret, R. (2011). Technology spillovers from foreign direct investment in Vietnam: Horizontal or vertical spillovers? Journal of the Asia Pacific Economy, 16(2), 183-201. https://doi.org/10.1080/13547860.2011.564746

Le, M., Hoang, V. N., Wilson, C., \& Ngo, T. (2020). Risk-adjusted efficiency and bank size in a developing economy: An analysis of Vietnamese banks. Journal of Economic Studies, 47(2), 386-404. https://doi.org/10.1108/JES-12-2018-0425

Le, V., Vu, X.-B. (Benjamin), \& Nghiem, S. (2018). Technical efficiency of small and medium manufacturing firms in Vietnam: A stochastic meta-frontier analysis. Economic Analysis and Policy, 59, 84-91. https://doi.org/10.1016/j.eap.2018.03.001

Liang, F. H. (2017). Does foreign direct investment improve the productivity of domestic firms? Technology spillovers, industry linkages, and firm capabilities. Research Policy, 46(1), 138-159. https://doi.org/10.1016/j.respol.2016.08.007

Lin, B., \& Atsagli, P. (2017). Inter-fuel substitution possibilities in South Africa: A translog production function approach. Energy, 121, 822-831. https://doi.org/10.1016/j.energy.2016.12.119

Lin, P., Liu, Z., \& Zhang, Y. (2009). Do Chinese domestic firms benefit from FDI inflow? Evidence of horizontal and vertical spillovers. China Economic Review, 20(4), 677-691. https://doi.org/10.1016/j.chieco.2009.05.010

Lu, Y., Tao, Z., \& Zhu, L. (2017). Identifying FDI spillovers. Journal of International Economics, 107, 75-90. https://doi.org/10.1016/j.jinteco.2017.01.006 
Markusen, J., \& Venables, A. J. (1999). Foreign direct investment as a catalyst for industrial development. European Economic Review, 43(2), 335-356. https://doi.org/10.1016/S0014-2921(98)00048-8

Newman, C., Rand, J., Talbot, T., \& Tarp, F. (2015). Technology transfers, foreign investment and productivity spillovers. European Economic Review, 76, 168-187.

https://doi.org/10.1016/j.euroecorev.2015.02.005

Ni, B., Spatareanu, M., Manole, V., Otsuki, T., \& Yamada, H. (2017). The origin of FDI and domestic firms' productivity - Evidence from Vietnam. Journal of Asian Economics, 52, 56-76. https://doi.org/10.1016/j.asieco.2017.08.004

Peltzman, S. (1977). The gains and losses from industrial concentration. Journal of Law \& Economics, 20(2), 229-263. https://doi.org/10.1086/466902

Peters, B. (2008). Innovation and firm performance. In ZEW Economic Studies: Vol. 38. Springer Science \& Business Media.

Ramstetter, E. D., \& Ngoc, P. M. (2013). Productivity, ownership, and producer concentration in transition: Further evidence from Vietnamese manufacturing. Journal of Asian Economics, 25, 28-42. https://doi.org/10.1016/j.asieco.2012.12.001

Rodríguez, A. C. (1996). Multinationals, linkages, and economic development. American Economic Association, 86(4), 852-873.

Schumpeter, J. (1912). The theory of economic development (Vol. 51). Oxford University Press.

Wang, E. T. G., \& Wei, H. L. (2005). The importance of market orientation, learning orientation, and quality orientation capabilities in TQM: An example from Taiwanese software industry. Total Quality Management and Business Excellence, 16(10), 1161-1177.

https://doi.org/10.1080/14783360500236270

Zhang, Y. (2019). Institutions, firm characteristics, and FDI spillovers. Emerging Markets Finance and Trade, 55(5), 1109-1136. https://doi.org/10.1080/1540496X.2018.1523057

\section{APPENDIX}

Table 6. Summary of meta technical inefficiency over regions, ownership and intensity (source: Vietnam's GSO and authors' calculation)

\begin{tabular}{|l|c|c|c|c|c|c|c|}
\hline Variable & $\mathrm{N}$ & mean & $\mathrm{p} 25$ & $\mathrm{p} 50$ & $\mathrm{p} 75$ & $\min$ & $\max$ \\
\hline MTI & 178700 & 0.1734 & 0.1289 & 0.1512 & 0.1869 & 0.0224 & 1.0000 \\
\hline South & 91422 & 0.1614 & 0.1239 & 0.1452 & 0.1752 & 0.0224 & 1.0000 \\
\hline North & 65076 & 0.1825 & 0.1338 & 0.1554 & 0.1950 & 0.0319 & 0.9998 \\
\hline Central & 22202 & 0.1958 & 0.1393 & 0.1671 & 0.2183 & 0.0351 & 0.9981 \\
\hline Ownership \\
\hline State & 3,180 & 0.1544 & 0.1203 & 0.1419 & 0.1690 & 0.0417 & 0.9981 \\
\hline Private & 155,517 & 0.1763 & 0.1309 & 0.1529 & 0.1892 & 0.0224 & 1.0000 \\
\hline Foreign & 22,202 & 0.1564 & 0.1133 & 0.1403 & 0.1754 & 0.0297 & 0.9983 \\
\hline Intensity & \multicolumn{7}{|l|}{} \\
\hline Labour & 68,461 & 0.1898 & 0.1423 & 0.1649 & 0.2030 & 0.0319 & 1.0000 \\
\hline Capital & 110,239 & 0.1631 & 0.1236 & 0.1423 & 0.1747 & 0.0224 & 1.0000 \\
\hline
\end{tabular}

Notes: This table describes the summary statistics of the dependent variable MTI over regions, ownership, and intensity. 